\title{
INVESTIGATING THE CHANGE OF SOIL RESISTENCE AND MOISTURE CONTENT IN THE CASE OF PRE-CROPS AND SOIL TILLAGE SYSTEMS
}

\author{
Rita Tury, Szilárd Tóth, Réka Láposi, László Fodor \\ Eszterházy Károly University, Faculty of Agricultural Sciences and Rural Development, Gyöngyös3200 Mátrai út 36. Hungary, \\ tury.rita@uni-eszterhazy.hu
}

\begin{abstract}
The experiments were set up in large parcels at the Fleischmann Rudolf Research Institute of Eszterházy Károly University located in Kompolt. We carried out measurements by using a Penetronik penetrometer (electrical soil cone penetrometer) at the experimental site, where brown grassland soil as well as clay washed brown forest soil are the typical soil types. The device used primarily serves to investigate the physical and water management properties of soils suitable for agricultural cultivation. The instrument is a hand-operated tool for registering soil mechanical resistance in Newtons (0-1000 N) and also the moisture content of the topsoil (\%) at the same time. The recording of the location of the measurement is made by the built-in GPS, and the results of the measurements are saved to the SD card of the device. The device's data acquisition unit allows direct reading of measurement results, serial measurements and computer processing of results $(0-70 \mathrm{~cm})$. Taking our objectives into consideration, we defined the location of measuring points with various numbers according to the properties of the examined fields. Besides designating measuring points at a distance of $0,5,10,15,20$ and $30 \mathrm{~m}$ from the edge of the fields, we designated two more in the middle of each field in all cases. The examined crop species included sand oats (Avena strigosa), baltacim (Onobrychis viciifolia) as well as common vetch (Vicia sativa L.) with oats as a companion crop. Summing up the measurement results, we have made the following statements: Low soil resistance $(127-131 \mathrm{~N})$ was experienced after soil loosening and oat-vetch with higher, well-preserved soil moisture content observed at each level, where the $50 \%$ moisture content of the soil started at the layer of $27 \mathrm{~cm}$ depth. Moderate soil resistance values (150-168 N) were manifested in the case of soil tillage with loosening and ploughing after sand oats. In this case, the $50 \%$ soil moisture content was observed at the layer of $38 \mathrm{~cm}$ depth. Higher soil resistance values were found (171-196 N) in the case of 2 and 3-year-old crops of baltacim, respectively, where the $50 \%$ soil moisture content was recorded from the layer of $58 \mathrm{~cm}$ depth. Based on the results, we consider it important to develop and improve soil tillage systems.
\end{abstract}

Keywords: soil resistance, penetrometer, guard band, soil tillage, pre-crop effect, soil moisture content [\%]

\section{INTRODUCTION}

Water is also of great importance from the agricultural point of view. It affects the biological activity of the soil, the material flow of the plants and the yield. Determining the water content of soil is useful for several reasons. Knowing this, we can determine the best time to cultivate the soil, the optimal sowing time and the type of crop to be grown, as well as we can get information about the soil moisture content that can be expected after various pre-crops.

Soil resistance, moisture content, and bulk density are among the most commonly examined soil physical parameters [1].

Electronic systems started to be used in agriculture in the mid-1960s [2]

DOI: 10.14232/analecta.2020.1.19-23 


\section{Analecta Technica Szegedinensia}

Over the past decades, powerful machinery used in agriculture has significantly contributed to the development of compacted soil layers [3] [4].

$34.8 \%$ of the soils in Hungary are particularly sensitive to compaction [5] [6]. Soil compaction is mostly influenced by the type of soil, its mechanical composition, cementing materials and soil use, as well as the level of the soil conservation structure (agrotechnical methods).

Soil resistance is an indicator expressing the relative degree of compaction, used in soil tillage systems to determine the state of soil [7] [8] [9]. On the one hand, it is due to the rapid feasibility of measurements and, on the other hand, it is possible to estimate the actual physical properties of the soil and the need for soil loosening [10].

In our experience, under the given circumstances, the size of soil resistance is primarily influenced by the cultivation depth, the cultivation tool applied as well as the pre-crops.

Soil resistance measured by using a penetrometer is one of the most commonly used methods for assessing soil compaction, the depth positioning of compacted layers and the spatial and temporal changes of the soil's physical properties [11]. Compaction blocks the formation of favourable porosity conditions, waterto-air ratio as well as that of microbial life, which is a condition of permanent structure [12].

With the help of a penetrometer, soil resistance and its current physical condition can be determined quickly and relatively accurately. The reliability of the soil resistance values (estimated value) measured by a penetrometer is determined by the accuracy of the measuring instrument, the performance of measurement and the inhomogeneity within the experimental plots [13].

In his studies related to soil compaction and moisture content experienced that in the dry years, the soil resistance values were generally higher due to lower moisture [14].

The purpose of our studies was to determine what effect the various crop species planned and cultivated according to the rules of crop rotation and the soil tillage systems following their removal have on the change of soil resistance and water content. Based on the results, suggestions can be made for the soil tillage systems to be applied after various crop species in order to achieve the lowest soil resistance (N) and highest soil moisture content [\%], which can be the basis for enhancing the fertility of the next crop.

\section{MATERIALS AND METHODS}

Our investigations were carried out at the areas of the Fleischmann Rudolf Research Institute of Eszterházy Károly University located in Kompolt. The typical soil type of the area is brown grassland soil as well as clay washed brown forest soil, which is characterized by good air, heat and water management, its ability to supply nutrients is also said to be good, however, in terms of its physical properties and cultivation it can be considered to be "almost short-term soil".

The examined crop species included sand oats (Avena strigosa), baltacim (Onobrychis viciifolia) as well as common vetch (Vicia sativa L.) with oats as a companion crop. Furthermore, we also investigated fallow, only disked plots.

Tillage variants of soil tillage comprised the examination of plots after subsoil loosening, ploughing as well as disking.

Taking our objectives into consideration, we defined the location of measuring points with various numbers according to the properties of the examined fields. Besides designating measuring points at a distance of $0,5,10,15,20$ and $30 \mathrm{~m}$ from the edge of the fields, we designated two more in the middle of each field in all cases.

We carried out measurements by using a Penetronik penetrometer (electrical soil cone penetrometer) at the experimental site, where brown grassland soil as well as clay washed brown forest soil are the typical soil types. The device used primarily serves to investigate the physical and water management properties of soils suitable for agricultural cultivation. The instrument is a hand-operated tool that allows registering both soil mechanical resistance in Newtons $(0-1000 \mathrm{~N})$ up to a depth of $70 \mathrm{~cm}$ and the moisture content of the topsoil (\%) at the same time. The recording of the location of the measurement is made by the built-in

DOI: 10.14232/analecta.2020.1.19-23 


\section{Analecta Technica Szegedinensia}

GPS, and the results of the measurements are saved to the SD card of the device. The device's data acquisition unit allows direct reading of measurement results, serial measurements and computer processing of results.

\section{RESULTS AND DISCUSSION}

Based on our investigations, in the case of the different soil tillage systems after the change of the various crop species our plots can be classified into 3 categories:

Category I includes the plots with subsoil loosening after the seed production of common vetch (Vicia sativa L.). The fallow disked areas were also classified into this category. As a result of complex effects, soil resistance in this group showed low values $(169,2 \mathrm{~N})$.

Category II includes the plots ploughed after sand oats as pre-crop (Avena strigosa), where the average values of soil resistance were already higher $(210,8 \mathrm{~N})$.

Category III includes the plots ploughed before crop establishment with the highest soil resistance $(224,3$ $\mathrm{N}$ ) in the case of baltacim (Onobrychis viciifolia) (Figure 1).

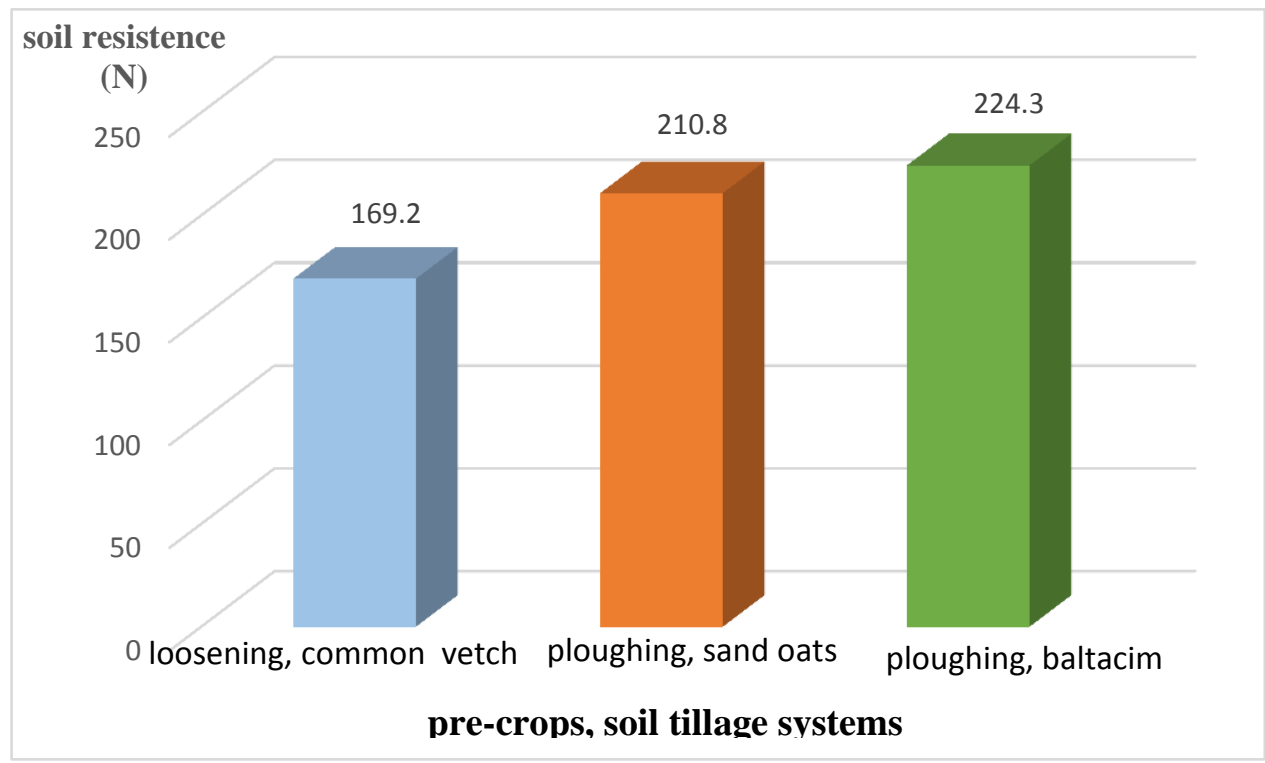

Source: Author's own editing (2019)

Figure 1 Changes in soil resistence content [N] in the case of various soil tillage systems and crops

The soil moisture content values [\%] were the most favourable in the loosened plots, where the layer below $27 \mathrm{~cm}$ depth reached 50\%; the crop species of category 1, the seed production of common vetch and oats falls into this category. In the case of ploughing after sand oats (the crop species of Category II) this value was measured at $38 \mathrm{~cm}$ depth, and in the case of baltacim (the crop species of category III) from $58 \mathrm{~cm}$ depth. (Figure 2) 


\section{Analecta Technica Szegedinensia}

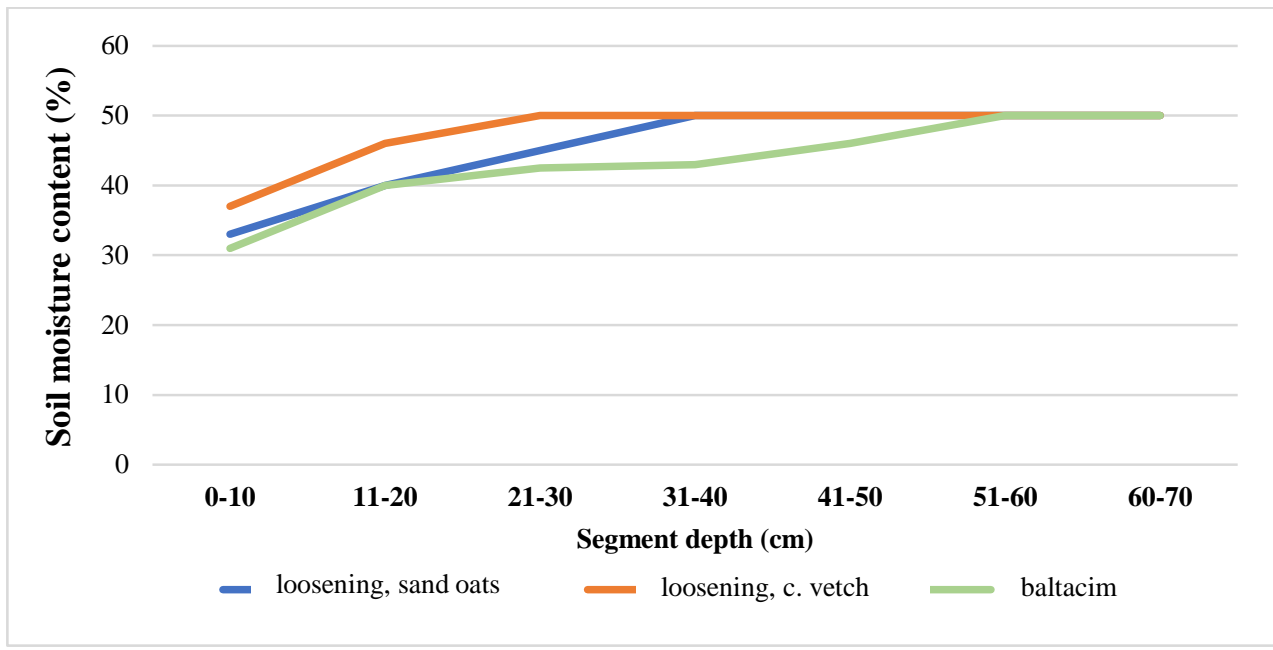

Source: Author's own editing (2019)

Figure 2 Changes in soil moisture content [\%] in the case of various soil management systems and pre-crops according to segment depth

\section{CONCLUSIONS}

Low soil resistance $(127-131 \mathrm{~N})$ was experienced after soil loosening and seed production of common vetch with oats as companion with higher, well-preserved soil moisture content observed at each level, where the 50\% moisture content of the soil started at the layer of $27 \mathrm{~cm}$ depth. Moderate soil resistance values (150-168 N) were detected in the case of tillage with loosening and ploughing after sand oats. In this case, the $50 \%$ soil moisture content was manifested from layer of $38 \mathrm{~cm}$ depth. Higher soil resistance values were measured (171-196 N) in the case of the 2 and 3-year-old crops of baltacim respectively, where the $50 \%$ soil moisture content was recorded from the layer of $58 \mathrm{~cm}$ depth. The high soil resistance values quantified on the basis of these studies predict the need for eliminating the baltacim crops and applying tillage systems based on loosening after their breaking up. Based on the results, we consider it important to develop and improve soil tillage systems.

\section{ACKNOWLEDGMENTS}

The first author's research was supported by the grant EFOP-3.6.1-16-2016-00001 ("Complex improvement of research capacities and services at Eszterhazy Karoly University")

\section{REFERENCES}

[1] Yule, I. J. - Kohen, G. - Nowak, M. (1999): A tractor performance monitor with DGPS capability. Computers and Electronics in Agriculture.23. pp. 155 -174.

[2] Stone, M. L. - Benneweis, R. K. - Bergejik, J. (2008): Evolution of Electronics for Mobile Agricultural Equpment. Transactions of theASABE.51. (2). pp. 385-390.

[3] Beke D.-Kismányoki T.-Tóth Z. (2005): Különböző müvelési módok hatása a talajtömörödésre. [Effect of Different Cultivation Methods on Soil Compaction] Növénytermelés vol. 54. no. 5-6. 411-425 pp.

[4] Ujj A. - Bencsik K. - Gyuricza Cs. - Singh M. K. (2005): Soil penetration resistance influenced by different method of primarily tillage and catch crop. Cereal Research Communications vol. 33 no. 1. 141-144 pp. 


\section{Analecta Technica Szegedinensia}

[5] Várallyay Gy. (2005): Talajvédelmi Stratégia az EU-ban és Magyarországon. [Soil Conservation Strategy in the European Union and in Hungary.] Agrokémia és Talajtan, 54. (1-2) pp. 203-216.

[6] Stefanovics P. (1997) Talajvédelem, környezetvédelem. [Soil protection, environmental protection.] Mezőgazdasági kiadó, Budapest

[7] Gyuricza CS. - Farkas Cs. - Baráth Csné - Birkás M. - Murányi A. (1998): A penetrációs ellenállás vizsgálata talajmüvelési tartamkísérletben gödöllői barna erdőtalajon. [Studies on Penetration Resistance in a Long-term Soil Tillage Experiment on Brown Forest Soil in Gödöllö]. Növénytermelés, 47: (2) 199-212. p.

[8] Birkás, M. (2001): Talajművelés a fenntartható mezőgazdaságban. [Soil Tillage in Sustainable Farming] ISBN 9639256 307. pp. 47-57.

[9] Bikás M., Stingli A., Farkas CS., Botlik, L. (2009): Összefüggés a művelés eredetű tömörödés és a klímakárok között. [Relationship between Tillage-induced Compaction and Climate-induced Damage.] Növénytermelés 58. 3. 5-26.

[10] Murer H., Werner A., Reshkin S., Wurin F. \& Biber J. (1991): Cellular mechanisms in proximal tubular reabsorption of inorganic phosphate. American Journal of Physiology 260, C885-889.

[11] Szőllősi, I. (2003): A 3T SYSTEM készülékkel mért penetrációs ellenállás és nedvességtartalom összefüggése vályog fizikai féleségü talajokon. [The Relationship between Penetration Resistance and Moisture Content Measured with a 3T SYSTEM Instrument on Adobe Soils.] Agrokémia és Talajtan.52.pp. 263-274.

[12] Schmidt R. - Szakál P. - Kerekes G. - Bene L. (1998): A talajtömörödöttségi viszonyok vizsgálata müvelőutas cukorrépa termesztési technológia alkalmazása esetén. [An Investigation of Soil Compaction Conditions in the Case of Sugar Beet Production Technology with Cultivation Route.] Cukorrépa 16: (1) 8-14.p

[13] Rátonyi T. (1999): A talaj fizikai állapotának penetrométeres vizsgálata talajmüvelési tartamkísérletben. [A Penetrometric Investigation of the Physical Condition of Soil in Long-term Tillage Experiments] Doktori (PhD) értekezés. Debrecen

[14] Beke D. (2006): Talajtömörödés és nedvességtartalom vizsgálat szántóföldi tartamkísérletekben. [Soil Compaction and Soil Moisture Studies in Long-term Field Experiments.] Doktori (PhD) értekezés. Keszthely 